\section{Protein Levels and Environmental Temperature Effects on Carcass Characteristics, Performance, and Nitrogen Excretion of Broiler Chickens from 7 to 21 Days of Age}

\section{ABSTRACT}

This trial was conducted to evaluate the utilization of low-protein diets formulated based on the ideal protein concept for broiler chickens from 7 to 21 days of age reared at different environmental temperatures. Nine hundred male Cobb-500 ${ }^{\circledR}$ chickens were used. At day seven chicks were distributed according to a completely randomized design in a $3 \mathrm{x}$ 3 factorial with four replications of 25 birds each. It was used three crude protein levels in the diet $(21.5 ; 20.0$ and 18.5\%) and three environmental temperatures (low, thermoneutral and high). The performance, carcass characteristics (yield and chemical composition), and nitrogen ingestion and excretion were assessed. There was no significant interaction among the factors for the evaluated variables. Environmental temperatures affected differently chicken performance. High environmental temperature resulted in lower weight gain and higher wing fat percentage, whereas cold temperature resulted in higher feed conversion. On the other hand, low-protein diets decreased weight gain, breast yield, nitrogen excretion and influenced breast and wings chemical composition. Birds reared at high environmental temperature showed lower nitrogen intake and excretion. The results showed that the decrease in protein levels from 7 to 21 days of age contributed to lower nitrogen excretion in broiler chickens, but impaired performance and carcass characteristics independent of rearing temperature.

\section{INTRODUCTION}

The broiler chickens development and productivity are highly influenced by dietary protein levels (Bregendahl et al., 2002) and environmental temperature (Ain Baziz et al., 1996) in the initial rearing period.

Since proteins have several functions in the living organism, it is important to provide adequate protein levels in the diet to guarantee optimum animal performance. Current studies have evaluated practices that allow the dietary protein levels reduction, since this would not only reduce the nitrogen excretion into the environment (Aletor et al., 2000; Bregendahl et al., 2002), but would also reduce diet costs because protein is an expensive nutrient. Nevertheless, the broilers' performance results fed low-protein diets in the initial phase are not conclusive. Some studies have shown that protein reduction does not influence performance (Summers et al., 1992; Deschepper \& De Groote, 1995), whereas other studies have shown impaired bird performance (Hussein et al., 2001; Bregendahl et al., 2002).

Based on the ideal protein concept, it is possible to reduce crude protein levels in broiler diets and fulfill the amino acid requirements by supplementation with synthetic amino acids. Therefore, diet formulation based on the ideal protein concept permits to provide amino acids at 
Faria Filho DE, Rosa PS, Vieira BS, Macari M, Furlan RL
Protein Levels and Environmental Temperature Effects on Carcass Characteristics, Performance, and Nitrogen Excretion of Broiler Chickens from 7 to 21 Days of Age the exact amounts and proportions needed for both maintenance and maximum protein deposition.

Chick development, mainly during the first weeks of age, is crucial for future performance, since some physiological processes will greatly influence body weight and feed conversion in the adult bird, e.g., cell hyperplasia and hypertrophy, maturation of the thermoregulatory system and cell differentiation in the gastrointestinal mucosa. It is well known that chick's thermoneutral temperature lies between 31 and $33^{\circ}$ $C$ in the first week of age. Therefore, higher temperatures than those may induce hyperthermia and dehydration, resulting in lower feed intake and delayed growth (Mickelberry et al., 1966). On the other hand, temperatures much lower than thermoneutral temperatures might result in hypothermia and induce pulmonary hypertension syndrome (ascites) (Maxwell \& Robertson, 1998).

Several practices might be adopted in order to minimize the impairment effects of high temperatures on the broiler chickens production characteristics. Some of these include management practices (feed restriction, rearing density), adequate housing and use of equipments (house height and localization, roof type, fans, fogging systems), genetic improvement (heat-resistant strains) and nutritional practices (levels of protein, energy and electrolyte in the diets). Among nutritional practices, the protein levels reduction is based on the fact that this nutrient has higher caloric increment than carbohydrates and lipids (Musharaf \& Latshaw, 1999). Therefore, for many years it has been recommended to reduce dietary protein contents to decrease the amount of heat produced by broilers during heat stress (Waldroup, 1982). However, recent studies have shown that the utilization of diets with low crude protein levels resulted in poor performance of broilers reared under heat stress during the growing phase (Alleman \& Leclerq, 1997; Faria Filho, 2003).

The objective of the present study was to evaluate the performance, carcass characteristics and nitrogen excretion of chicks from 7 to 21 days of age reared at low, thermoneutral or high temperatures and fed diets containing different protein levels formulated on ideal protein concept.

\section{MATERIAL AND METHODS}

Male Cobb- $500^{\circledR}$ chicks were fed a control diet (Table 1) and reared at thermoneutral temperature (32 $\left.\pm 2^{\circ} \mathrm{C}\right)$ and relative humidity of $55 \pm 13 \%$ between one and seven days of age (pre-experimental period). At seven days of age, 900 birds with body weight average of $162.1 \pm 1.3 \mathrm{~g}$ were distributed into nine treatments according to a completely randomized design in a $3 \times 3$ factorial arrangement, with four repetitions of 25 birds each. The studied factors were crude protein levels $(21.5 ; 20.0$ and $18.5 \%$ ) and environmental temperature (low, thermoneutral and high). Water and diets were provided ad libitum and the birds were managed according to standard commercial practices.

\begin{tabular}{|c|c|c|c|}
\hline \multirow[t]{2}{*}{ Ingredients } & \multirow{2}{*}{$\begin{array}{c}\text { Crude protein } \\
21.5 \% \\
\text { (control) }\end{array}$} & \multicolumn{2}{|c|}{ Ideal protein } \\
\hline & & $20.0 \%$ & $8.5 \%$ \\
\hline Corn & 54.72 & 60.45 & 66.76 \\
\hline Soybean meal & 36.62 & 31.10 & 24.91 \\
\hline Soybean oil & 4.76 & 3.70 & 2.53 \\
\hline Dicalcium phosphate & 1.77 & 1.83 & 1.89 \\
\hline Calcitic limestone & 1.08 & 1.08 & 1.08 \\
\hline Salt & 0.45 & 0.30 & 0.13 \\
\hline Sodium bicarbonate & - & 0.23 & 0.49 \\
\hline Potassium chloride $60 \%$ & - & 0.16 & 0.33 \\
\hline Choline chloride $60 \%$ & 0.10 & 0.10 & 0.10 \\
\hline Coxistac $12 \%$ & 0.05 & 0.05 & 0.05 \\
\hline Zinc bacitracin $15 \%$ & 0.03 & 0.03 & 0.03 \\
\hline Vitamin/mineral supplement & 0.10 & 0.10 & 0.10 \\
\hline L-lysine & - & 0.18 & 0.39 \\
\hline DL-methionine & 0.32 & 0.30 & 0.35 \\
\hline L-threonine & - & 0.08 & 0.17 \\
\hline L-tryptophan & - & 0.03 & 0.05 \\
\hline L-valine & - & 0.13 & 0.23 \\
\hline L-arginine & - & 0.07 & 0.23 \\
\hline L-isoleucine & - & 0.08 & 0.18 \\
\hline Total & 100.00 & 100.00 & 00.00 \\
\hline Energy and nutrients & \multicolumn{3}{|c|}{ Calculated composition } \\
\hline Metabolizable energy $(\mathrm{kcal} / \mathrm{kg}$ & 3,080 & 3,080 & 3,080 \\
\hline Crude protein (\%) & 21.5 & 20.0 & 18.5 \\
\hline Calcium (\%) & 0.97 & 0.97 & 0.97 \\
\hline Available phosphorus (\%) & 0.47 & 0.47 & 0.47 \\
\hline Potassium (\%) & 0.90 & 0.90 & 0.90 \\
\hline Sodium (\%) & 0.20 & 0.20 & 0.20 \\
\hline Chloride (\%) & 0.35 & 0.35 & 0.35 \\
\hline \multicolumn{4}{|l|}{ Digestible amino acids (\%) } \\
\hline Lysine & 1.13 & 1.13 & 1.13 \\
\hline Methionine + cystine & 0.87 & 0.81 & 0.81 \\
\hline Threonine & 0.17 & 0.18 & 0.18 \\
\hline Tryptophan & 0.76 & 0.76 & 0.76 \\
\hline Valine & 1.27 & 1.19 & 1.19 \\
\hline Arginine & 0.77 & 0.76 & 0.76 \\
\hline Isoleucine & 0.83 & 0.87 & 0.87 \\
\hline Leucine & 1.65 & 1.52 & 1.36 \\
\hline Histidine & 0.52 & 0.47 & 0.42 \\
\hline Phenylalanine+tyrosine & 1.51 & 1.37 & 1.21 \\
\hline Essential/Non-essential amino & acids49:51 & $50: 50$ & $52: 48$ \\
\hline \multicolumn{4}{|c|}{$\begin{array}{l}1 \text { - Levels per } \mathrm{kg} \text { of diet: } 1,500 \mathrm{IU} \text { Vitamin } \mathrm{A} ; 500 \mathrm{IU} \text { Vitamin } \mathrm{D} 3 ; 20 \\
\mathrm{mg} \text { vitamin } \mathrm{E} ; 0.5 \mathrm{mg} \text { vitamin } \mathrm{K} ; 2 \mathrm{mg} \text { vitamin B1; } 6.6 \mathrm{mg} \text { vitamin } \mathrm{B} 2 \\
20 \mathrm{mcg} \text { vitamin B12; } 0.1 \mathrm{mg} \text { folic acid; } 10 \mathrm{mg} \text { pantothenic acid; } 100 \\
\mathrm{mg} \text { niacin; } 125 \mathrm{mg} \text { antioxidant; } 10 \mathrm{mg} \mathrm{Cu} 55 \mathrm{mg} \mathrm{Fe} ; 1.365 \mathrm{mg} \mathrm{l} \text {; } \\
88 \mathrm{mg} \mathrm{Mn} ; 0.25 \mathrm{mg} \mathrm{Se} ; 100 \mathrm{mg} \mathrm{Zn.}\end{array}$} \\
\hline
\end{tabular}


Faria Filho DE, Rosa PS, Vieira BS, Macari M, Furlan RL
The crude protein levels (Micro-Kjeldahl) and amino acid (chromatography) in the corn and soybean meal that were used in the diets were previously evaluated according to AOAC (1984). Low-protein diets were formulated based on the ideal protein concept, so that the requirements of digestible amino acids were expressed as a percentage of digestible lysine (Baker \& Han, 1994), as follows: methionine+cystine $72 \%$, threonine $67 \%$, tryptophan $16 \%$, valine $77 \%$, arginine $105 \%$ and isoleucine $67 \%$. The leucine, histidine and phenylalanine+tyrosine levels were closer to the ideal proportion proposed by Baker \& Han (1994), i.e., 109, 32 and $105 \%$ of lysine, respectively, with the decreasing levels of crude protein (Table 1). The diets contained similar levels of nutrients, except for protein and amino acid levels. Diet samples were also collected for crude protein and amino acid analyses (AOAC, 1984). The actual protein and amino acid values were similar to the calculated values.

During the experimental period (7 to 21 days), the birds were distributed into three environmentally controlled rooms with low, thermoneutral and high temperatures (Table 2). Heating was provided by infrared lamps and cooling was provided by cooling unities. The temperature was controlled by thermostats.

\begin{tabular}{lcc}
\hline $\begin{array}{l}\text { Table } \mathbf{2} \text { - Environmental temperature and relative humidity } \\
\text { measured from } 7 \text { to } 21 \text { days of age. } \\
\text { Environmental } \\
\text { temperature }\left(^{\circ} \mathbf{C}\right)\end{array}$ & $\begin{array}{c}\text { Relative } \\
\text { humidity }(\%)\end{array}$ \\
$\begin{array}{c}\text { Low } \\
07 \text { to } 14 \text { days } \\
15 \text { to } 21\end{array}$ & $\begin{array}{c}21.1 \pm 1.37 \\
18.3 \pm 1.2\end{array}$ & $60.8 \pm 10.9$ \\
$\begin{array}{c}\text { Thermoneutral } \\
07 \text { to } 14 \text { days }\end{array}$ & $29.0 \pm 0.9$ & $72.1 \pm 9.1$ \\
15 to 21 & $26.3 \pm 1.5$ & $54.2 \pm 9.9$ \\
High $\quad 33.6 \pm 0.9$ & $72.6 \pm 10.9$ \\
07 to 14 days & $33.3 \pm 0.7$ & $50.8 \pm 8.4$ \\
15 to 21 & & $57.4 \pm 11.3$ \\
\hline
\end{tabular}

${ }^{1}$ Mean \pm standard deviation.

Production characteristics (feed intake, weight gain and feed conversion) were evaluated from 7 to 21 days of age. Carcass yield, abdominal fat percentage and breast, thighs+drumsticks and wings yields were evaluated at 21 days in two birds per replication. Commercial cuts were made only by one person that had been previously trained. Carcass yield and percentage of abdominal fat were expressed as a function of the live weight and the other characteristics were expressed as a function of carcass weight with feet and head. Dry matter, ether extract, crude protein
Protein Levels and Environmental Temperature Effects on Carcass Characteristics, Performance, and Nitrogen Excretion of Broiler Chickens from 7 to 21 Days of Age

and ashes were evaluated in the breast, thighs+ drumsticks and wings according to the recommendations of AOAC (1984).

Nitrogen ingestion was calculated multiplying feed intake by dietary nitrogen levels. Nitrogen retention was evaluated in a reference slaughter of 20 birds at 7 days and two birds per experimental unity at 21 days of age. Whole birds were ground (with feathers, blood and viscera), and nitrogen levels were determined. Nitrogen retention was calculated as the difference between nitrogen levels at 21 and 7 days of age. Nitrogen excretion was estimated as ingested nitrogen minus retained nitrogen in the organism. The nitrogen levels in the carcasses and diets were assessed using the Micro-Kjeldahl method (AOAC, 1984).

The statistical package $\mathrm{SAS}^{\circledR}$ was used to assess the normal distribution of the studentized errors (Cramer-Von Mises test) and the homogeneity of variance (Brown-Forsythe test). After it has been assured that all presuppositions of the model had been attended, data were submitted to analysis of variance using the General Linear Models (GLM) procedure of SAS $^{\circledR}$ (SAS Institute, 2002). Statistically different means $(p<0.05)$ were compared using the Tukey's test at $5 \%$ of probability.

\section{RESULTS AND DISCUSSION}

Feed intake, weight gain and feed conversion results are shown in Table 3 . There were no significant interactions between dietary crude protein levels and environmental temperature for these characteristics.

\begin{tabular}{|c|c|c|c|}
\hline \multirow[t]{2}{*}{ Factors } & \multicolumn{3}{|c|}{ Characteristics } \\
\hline & $\begin{array}{l}\text { Feed in } \\
\text { take }(g)\end{array}$ & $\begin{array}{l}\text { Weight } \\
\text { gain (g) }\end{array}$ & $\begin{array}{c}\text { Feed } \\
\text { conversion }(g / g)\end{array}$ \\
\hline \multicolumn{4}{|c|}{ Environmental temperature } \\
\hline Low & $1006 \pm 24.5 a^{1}$ & $667 \pm 20.2 b$ & $1.51 \pm 0.06 \mathrm{c}$ \\
\hline Thermoneutral & $991 \pm 21.6$ a & $720 \pm 21.4 a$ & $1.38 \pm 0.04 \mathrm{a}$ \\
\hline High & $788 \pm 26.9$ b & $540 \pm 30.8 \mathrm{c}$ & $1.46 \pm 0.06 \mathrm{~b}$ \\
\hline \multicolumn{4}{|c|}{ Crude protein (\%) } \\
\hline 21.5 (control) & $929 \pm 97.0$ & $663 \pm 74.3 \mathrm{a}$ & $1.40 \pm 0.07 \mathrm{a}$ \\
\hline 20.0 & $934 \pm 116.5$ & $641 \pm 86.9 \mathrm{~b}$ & $1.46 \pm 0.08 b$ \\
\hline 18.5 & $923 \pm 104.7$ & $623 \pm 81.1 c$ & $1.48 \pm 0.06 b$ \\
\hline CV $(\%)$ & 2.54 & 2.78 & 2.87 \\
\hline
\end{tabular}

The main effects (Table 3 ) indicated that chicks reared at high environmental temperature showed lower feed intake in comparison to the birds subjected 
Faria Filho DE, Rosa PS, Vieira BS, Macari M, Furlan RL
Protein Levels and Environmental Temperature Effects on Carcass Characteristics, Performance, and Nitrogen Excretion of Broiler Chickens from 7 to 21 Days of Age to low or thermoneutral temperatures. Since energy requirements for maintenance decrease with increasing environmental temperature, heat stress adaptation involves the feed intake reduction as an attempt to reduce the production of endogenous heat (Daghir, 1995). On one hand, feed intake of birds reared at low environmental temperature was not different from birds at thermoneutral temperature, which might be due to bird behavior in order to conserve heat. At low environmental temperatures, the birds spend most of the time in groups as a means to decrease heat dissipation, and therefore the time spent eating or drinking water is reduced (Furlan \& Macari, 2002).

The present results showed that environmental temperature affected body weight gain. Birds reared at thermoneutral temperature showed higher weight gain than birds submitted to low or high environmental temperatures, and the worst results were seen in the birds kept under high temperatures (Table 3). It was also seen that the birds reared at low environmental temperature showed higher feed conversion, whereas birds raised at thermoneutral temperature showed better feed conversion. Intermediate feed conversion was seen in the high temperature-reared birds. Such results indicate that the energy spent to produce heat in the low environmental temperature was greater than the energy spent to dissipate heat in the high temperature. Indeed, high environmental temperatures are essential for chicks in the initial phase. Besides the fact that their thermoregulatory system is not completely developed yet, their area/volume ratio is greater; therefore, more heat is dissipated (Furlan \& Macari, 2002).

Crude protein levels had no effect on feed intake; nevertheless, body weight gain and feed conversion were impaired with decreasing protein levels in the diet. Similar results have been observed by Hussein et al. (2001) and Bregendahl et al. (2002), i.e., that reported decreased performance of birds fed lowprotein diets. Other studies have also reported that protein levels had no effects on feed intake (Ferguson et al., 1998; Araújo, 2001). Gonzales (2002) stated that the diet intake control is affected not only by the protein content, but also by protein quality, i.e., amino acid balance. In the present study, low-protein diets showed no amino acid deficiency, which contributed to the similar results of feed intake.

The reasons for the performance decrease in broilers fed low-protein diets have been studied by Rérat et al. (1992) cited by Bregendahl et al. (2002). It has been suggested that lower concentrations of free amino acids are found in the portal blood if diets are supplemented with synthetic amino acids in comparison to amino acids from intact protein (corn and soybean meal). This indicates that free amino acids are preferably metabolized within enterocytes, decreasing their bio-availability if compared to the amino acids provided as peptides (intact protein). Pinchasov et al. (1990) and Rutz (2002) reported that peptides from the digestion of intact proteins are absorbed more rapidly by enterocytes than the free amino acids of diets supplemented with synthetic amino acids. The lower absorption rate of synthetic amino acids results in lower availability of essential amino acids for protein synthesis in the tissues (Pinchasov et al., 1990). Besides, Batal \& Parsons (2002) have shown that purified diets containing $14.4 \%$ of crude protein and ideal profile of amino acids resulted in lower villi height and width and smaller crypt depth in comparison to a corn and soybean-based diet with $23 \%$ of protein. The present findings also indicated that birds fed low protein levels had worse performance. The diets with $21.5 ; 20.0$ and $18.5 \%$ of protein had $99.1 ; 96.4$ and $91.9 \%$ of intact protein (corn +soybean meal), respectively. The remaining nitrogen was provided by synthetic amino acids. Such findings demonstrate the importance of intact protein on the initial performance of broiler chickens.

There was no significant interaction between rearing temperature and dietary protein levels on the carcass yields and commercial cuts, and on abdominal fat percentage (Table 4). Nevertheless, at hightemperature birds showed better carcass yield in relation to birds reared at low and thermoneutral temperatures, which were not different. Such results are related to lower development rate of the viscera and slower feathering in high temperature birds, allowing a proportional increase in carcass yield (Ain Baziz et al., 1996). Although the birds submitted to high environmental temperature have shown the best carcass yield, this fact was not reflected in the absolute body weight gain (Table 3 ).

The reduction in protein levels had no effects on the carcass and wings yields, however, reduces breast yield and increases thigh+drumstick yield. Summers et al. (1988) reported no decrease in breast meat yield at 21 days of age in birds fed low-protein diets. On the other hand, birds fed low-protein diets in the initial phase had lower breast yield at 42, 49 and 56 days of age (Salmon et al., 1983). The control diet resulted in lower percentage of abdominal fat in comparison to the diet with $18.5 \% \mathrm{CP}$, corroborating results reported 


\begin{tabular}{|c|c|c|c|c|c|}
\hline \multirow[t]{2}{*}{ Factors } & \multicolumn{5}{|c|}{ Characteristics (\%) ${ }^{1}$} \\
\hline & Carcass & Breast & Legs & Wings & Fat \\
\hline \multicolumn{6}{|c|}{ Environmental temperature } \\
\hline Low & $81.80 \pm 0.92 b^{1}$ & $25.15 \pm 1.16 \mathrm{a}$ & $26.11 \pm 0.80$ & $10.65 \pm 0.46 b$ & $1.09 \pm 0.35 b$ \\
\hline Thermoneutral & $81.25 \pm 0.88 \mathrm{~b}$ & $24.10 \pm 1.10 \mathrm{~b}$ & $26.48 \pm 0.73$ & $10.96 \pm 0.54 \mathrm{ab}$ & $1.46 \pm 0.24 \mathrm{a}$ \\
\hline High & $83.71 \pm 1.05 a$ & $23.98 \pm 1.09 b$ & $26.60 \pm 0.49$ & $11.25 \pm 0.49 a$ & $1.54 \pm 0.33 a$ \\
\hline \multicolumn{6}{|c|}{ Crude protein (\%) } \\
\hline 21.5 (control) & $82.17 \pm 1.15$ & $25.01 \pm 0.97 a$ & $26.05 \pm 0.51 b$ & $11.08 \pm 0.49$ & $1.17 \pm 0.31 b$ \\
\hline 20.0 & $82.41 \pm 1.59$ & $24.65 \pm 1.09 a$ & $26.23 \pm 0.71 b$ & $10.95 \pm 0.52$ & $1.40 \pm 0.43 \mathrm{ab}$ \\
\hline 18.5 & $82.18 \pm 1.57$ & $23.57 \pm 1.13 b$ & $26.92 \pm 0.58 a$ & $10.82 \pm 0.63$ & $1.52 \pm 0.26 a$ \\
\hline CV $(\%)$ & 1.18 & 3.98 & 2.24 & 4.42 & 20.55 \\
\hline
\end{tabular}

1 - Means \pm standard deviation followed by different letters in the same column and within each factor are different by Tukey's test (5\%).

by Kerr \& Kidd (1999) and Aletor et al. (2000) in market-age broiler chickens.

Breast and wing yields were significantly affected by environmental temperature (Table 4). There was a reduction in breast yield and an increase in wing yield in birds kept at high environmental temperature compared to low temperature birds. The energetic characteristics of muscle fibers are related to the differential effect of heat on the breast meat and wing meat. Ain Baziz et al. (1996) observed that broilers chronically exposed to heat showed proportional reduction in breast meat, whereas the leg meat was slightly reduced. Howlider \& Rose (1989) also reported a reduction in breast muscle, but no changes in red meat (thighs), which has mostly red fibers and oxidative enzymes. The reduction in muscle growth observed during heat exposure suggests changes in the growth of different fiber types, through changes in the metabolism and in the rates of protein synthesis and degradation.

Some researches have shown that body composition, particularly carcass fat, might be influenced by environmental factors such as temperature. Kubena et al. (1974) reported that the increase in environmental temperature resulted in higher percentage of abdominal fat. According to Howlider \& Rose (1987) there were increases of $0.81 \%$ and $1.6 \%$ in abdominal fat and total carcass fat of broilers, respectively, for each degree increased in the environmental temperature. The present findings also showed higher abdominal fat percentages in the birds reared at thermoneutral and high temperatures when compared to the low temperature. According to Ain Baziz et al. (1996) the higher fat deposition in broilers reared at high environmental temperature is due an increase in lipoprotein lipase enzyme activity in the birds adipose tissue. This enzyme is responsible for fatty acids release from lipoproteins and incorporation in adipocytes.

The values in Table 5 show that there was no interaction between environmental temperature and crude protein levels on the breast and thighs+ drumsticks chemical composition. Environmental temperature had no effects on the chemical composition of breast and thighs+drumsticks, although the increase in temperature resulted in decreasing protein levels and increasing fat contents in the wings. Crude protein levels in the diet had no effect on the

Table 5 - Means of dry matter (MS, \%), crude protein (\%MS), ether extract (\%MS) and ash (\%MS) of the breast, thighs+drumsticks (Legs) and wings of broilers at 21 days of age.

\begin{tabular}{|c|c|c|c|c|c|c|c|c|}
\hline \multirow{2}{*}{\multicolumn{2}{|c|}{ Characteristics (\%) }} & \multicolumn{3}{|c|}{ Environmental temperature $\left({ }^{\circ} \mathrm{C}\right)$} & \multicolumn{3}{|c|}{ Crude protein (\%) } & \multirow[t]{2}{*}{ CV (\%) } \\
\hline & & Low & Neutral & High & 21.5 & 20.0 & 18.5 & \\
\hline \multirow{4}{*}{ Breast } & Dry matter & $28.7 \pm 0.18$ & $28.7 \pm 0.16$ & $28.7 \pm 0.14$ & $28.6 \pm 0.08 b$ & $28.6 \pm 0.07 b$ & $29.7 \pm 0.08 \mathrm{a}$ & 1.26 \\
\hline & Crude protein & $64.7 \pm 0.93$ & $64.6 \pm 0.76$ & $64.5 \pm 0.94$ & $64.8 \pm 0.90$ & $64.8 \pm 0.56$ & $64.2 \pm 1.00$ & 1.40 \\
\hline & Ether extract & $24.7 \pm 0.77$ & $24.8 \pm 0.82$ & $24.7 \pm 0.97$ & $24.2 \pm 0.23 b$ & $24.1 \pm 0.23 b$ & $25.8 \pm 0.41 a$ & 1.27 \\
\hline & Ash & $10.5 \pm 0.80$ & $10.6 \pm 1.06$ & $10.8 \pm 1.22$ & $10.9 \pm 0.85 \mathrm{ab}$ & $11.1 \pm 0.69 a$ & $9.9 \pm 1.13 b$ & 9.01 \\
\hline \multirow{4}{*}{ Legs } & Dry matter & $30.3 \pm 0.17$ & $30.4 \pm 0.20$ & $30.7 \pm 0.21$ & $30.4 \pm 0.22$ & $30.4 \pm 0.20$ & $30.7 \pm 0.18$ & 1.44 \\
\hline & Crude protein & $50.8 \pm 1.56$ & $50.4 \pm 1.22$ & $48.8 \pm 1.20$ & $50.9 \pm 1.12$ & $50.7 \pm 1.07$ & $48.4 \pm 1.21$ & 1.54 \\
\hline & Ether extract & $31.7 \pm 1.68$ & $35.8 \pm 1.46$ & $38.1 \pm 1.48$ & $34.3 \pm 2.90$ & $34.2 \pm 2.87$ & $37.1 \pm 2.75$ & 1.82 \\
\hline & Ash & $17.5 \pm 0.90$ & $13.8 \pm 0.97$ & $13.1 \pm 0.65$ & $14.9 \pm 2.24$ & $15.1 \pm 2.06$ & $14.4 \pm 2.17$ & 5.95 \\
\hline \multirow{4}{*}{ Wings } & Dry matter & $32.8 \pm 0.12$ & $32.8 \pm 0.08$ & $32.6 \pm 0.14$ & $32.7 \pm 0.05$ & $32.8 \pm 0.04$ & $32.9 \pm 1.00$ & 1.16 \\
\hline & Crude protein & $50.9 \pm 1.37 a$ & $48.6 \pm 1.91 \mathrm{~b}$ & $49.0 \pm 1.83 \mathrm{~b}$ & $50.7 \pm 1.03 a$ & $48.9 \pm 2.37 b$ & $47.9 \pm 1.88 b$ & 2.21 \\
\hline & Ether extract & $35.0 \pm 0.43 c$ & $37.7 \pm 2.88 b$ & $38.4 \pm 2.30 \mathrm{a}$ & $34.9 \pm 1.06 c$ & $37.7 \pm 2.13 b$ & $38.6 \pm 2.73 a$ & 1.78 \\
\hline & Ash & $14.2 \pm 1.51$ & $14.7 \pm 1.74$ & $12.5 \pm 0.93$ & $14.4 \pm 1.79$ & $13.4 \pm 1.64$ & $13.5 \pm 1.54$ & 9.5 \\
\hline
\end{tabular}

1 - Means \pm standard deviation followed by different letters in the same row and within each factor are different by the Tukey's test $(p<0.05)$. 
Faria Filho DE, Rosa PS, Vieira BS, Macari M, Furlan RL
Protein Levels and Environmental Temperature Effects on Carcass Characteristics, Performance, and Nitrogen Excretion of Broiler Chickens from 7 to 21 Days of Age chemical composition of thighs+drumsticks. Nevertheless, the fat and ash deposition were higher and lower, respectively, in the breast of broilers fed low-protein diets. Low-protein diets have also increased fat deposition and decreased protein deposition in the wings.

The environmental temperatures and dietary crude protein levels effects on the ingestion and excretion of nitrogen in chicks from 7 to 21 days of age are shown in Table 6. There was no significant interaction between the factors for these variables. Although feed intake has not been influenced by crude protein levels in the diet (Table 3), nitrogen ingestion decreased with the reduction in dietary protein levels. In regard to environmental temperature, nitrogen ingestion decreased with increasing environmental temperature, as a result of lower feed intake (Table 3).

\begin{tabular}{|c|c|c|}
\hline \multicolumn{3}{|c|}{$\begin{array}{l}\text { Table } 6 \text { - Means of nitrogen ingestion and excretion of broiler } \\
\text { chickens from } 7 \text { to } 21 \text { days of age. }\end{array}$} \\
\hline \multirow[t]{2}{*}{ Factors } & \multicolumn{2}{|c|}{ Nitrogen (g/bird) } \\
\hline & Ingestion & Excretion \\
\hline \multicolumn{3}{|c|}{ Environmental temperature } \\
\hline Low & $35.7 \pm 2.37 a^{1}$ & $14.1 \pm 1.93 a$ \\
\hline Thermoneutral & $35.1 \pm 1.82$ a & $11.5 \pm 0.81 b$ \\
\hline High & $27.9 \pm 2.07 b$ & $11.3 \pm 1.62 b$ \\
\hline \multicolumn{3}{|l|}{ Crude protein (\%) } \\
\hline 21.5 (control) & $35.1 \pm 3.66 a$ & $13.8 \pm 1.78 a$ \\
\hline 20.0 & $33.1 \pm 4.12 b$ & $12.2 \pm 1.69 \mathrm{~b}$ \\
\hline 18.5 & $30.6 \pm 3.47 c$ & $10.8 \pm 1.33 \mathrm{c}$ \\
\hline CV $(\%)$ & 2.55 & 6.90 \\
\hline
\end{tabular}

1 - Means \pm standard deviation followed by different letters in the same column and within each factor are different by the Tukey's test $(5 \%)$.

Nitrogen excretion gradually decreased with reducing levels of crude protein in the diet. Diets with 20 and $18.5 \%$ of protein decreased nitrogen excretion in 11.6 and $21.7 \%$, respectively, in comparison to the control diet. Such results are in accordance with previously results of Blair et al. (1999) that concluded that nitrogen excretion might be reduced between 10 and $27 \%$ with decreasing diet protein levels. Although low-protein diets in the present study have caused lower nitrogen excretion, their use is not justified, since broiler performance has been impaired (Table 3).

\section{CONCLUSIONS}

The dietary protein levels reduction from 7 to 21 days of age contributed to lower nitrogen excretion, however, impaired performance, yield and commercial cuts composition in broiler chickens, independent of the rearing temperature.

\section{REFERENCES}

Ain Baziz HA, Geraert PA, Padilha JCF, Guillaumin S. Chronic heat exposure enhances fat deposition and modifies muscle and fat partition in broiler carcasses. Poultry Science 1996; 75(4):505-513.

Aletor VA, Hamid II, Nieb E, Pfeffer E. Low-protein amino acidsupplemented diets in broiler chickens:effects on performance, carcass characteristics, whole body composition and efficiencies of nutrient utilization. Journal of the Science of Food and Agriculture 2000; 80:547-554.

Alleman F, Leclercq B. Effect of dietary protein and environmental temperature on growth performance and water consumption of male broiler chickens. British Poultry Science 1997; 38:607-610.

Association of Official Analytical Chemists - AOAC. Official methods of analysis of the association of official analytical chemists. $14^{\text {th }}$ ed. Washington, DC; 1984.

Araújo LF. Estudo de diferentes critérios de formulação de rações, com base em perfis de aminoácidos totais e digestíveis para frangos de corte [tese]. Jaboticabal (SP):Universidade Estadual Paulista; 2001.

Baker DH, Han Y. Ideal amino acid profile for chicks during the first three weeks posthatching. Poultry Science 1994; 73:1441-1447.

Batal $A B$, Parsons $C M$. Effects of age on development of digestive organs and performance of chicks fed a corn-soybean meal versus a crystalline amino acid diet. Poultry Science 2002; 81:1338-1341.

Blair R, Jacob JP, Ibrahim S, Wang P. A quantitative assessment of reduced protein diets and supplements to improve nitrogen utilization. Journal of Applied Poultry Research 1999; 8:25-47.

Bregendahl K, Sell JL, Zimmerman DR. Effect of low-protein diets on growth performance and body composition of broiler chicks. Poultry Science 2002; 81:1156-1167.

Daghir NJ. Poultry production in hot climates. Cambridge: Cambridge University Press; 1995.

Deschepper K, De Groote G. Effect of dietary protein, essential and non essential amino acids on the performance and carcass composition of male broiler chickens. British Poultry Science 1995; 36:229-245

Faria Filho DE. Efeito de dietas com baixo teor protéico, formuladas usando o conceito de proteína ideal, para frangos de corte criados em temperaturas fria, termoneutra e quente [dissertação]. Jaboticabal (SP):Universidade Estadual Paulista; 2003.

Ferguson NS, Gates RS, Taraba JL, Cantor AH, Pescatore AJ, Ford MJ, Burnham DJ. The effect of dietary protein on growth, ammonia concentration, and litter composition in broilers. Poultry Science 1998; 77:1481-1486.

Furlan RL, Macari M. Termorregulação. In: Macari M, Furlan RL, Gonzales E, editores. Fisiologia aviária: aplicada a frangos de corte. 2. ed. Jaboticabal:FUNEP; 2002. p. 209-230. 
Gonzales E. Ingestão de alimentos: mecanismos regulatórios. In: Macari M, Furlan RL, Gonzales E, editores. Fisiologia aviária: aplicada a frangos de corte. 2. ed. Jaboticabal:FUNEP; 2002. p. 187-199.

Howlider MAR., Rose SP. Temperature and the growth of broilers. World's Poultry Science Journal 1987; 43:228-237.

Howlider MAR, Rose SP. Rearing temperature and the meat yield of broilers. British Poultry Science 1989; 30:61-67.

Hussein AS, Cantor AH, Pescatore AJ. Effect of low protein diets with amino acid supplementation on broiler growth. Journal of Applied Poultry Research 2001; 10:354-362.

Kerr BJ, Kidd MT. Amino acid supplementation of low-protein broiler diets: 2. Formulation on an ideal amino acid basis. Journal of Applied Poultry Research 1999; 8:310-320.

Kubena LF, Deaton JW, Chen TC, Reece FN. Factors influencing the quantity of abdominal fat in broilers. 1. Rearing temperature, sex, age or weight, and dietary choline chloride and inositol supplementation. Poultry Science 1974; 53:211-214.

Maxwell MH, Robertson GW. UK survey of broiler ascites and sudden death syndromes in 1993. British Poultry Science 1998; 39:203215.

Mickelberry WC, Rogler JC, Stadelman WJ. The influence of dietary fat and environmental temperature upon chick growth and carcass composition. Poultry Science 1966; 45:313-321.

Musharaf NA, Latshaw, JD. Heat increment as affected by protein and amino acid nutrition. World's Poultry Science 1999; 55:233240.

Pinchasov $Y$, Mendonça CX, Jensen LS. Broiler chick response to low protein diets supplemented with synthetic amino acids. Poultry Science 1990; 69:1950-1955.

Rutz F. Proteínas: digestão e absorção. In: Macari M, Furlan RL, Gonzales E, editores. Fisiologia aviária: aplicada a frangos de corte. 2. ed. Jaboticabal:FUNEP; 2002. p. 135-141.

Salmon RE, Classen HL, Mc Millan RK. Effect of starter and finisher protein on performance, carcass grade and meat yield of broilers. Poultry Science 1983; 62:837-845.

SAS INSTITUTE. SAS ${ }^{\circledR}$ user's guide: statistics. Cary; 2002.

Summers JD, Lesson S, Spratt D. Yield and composition of edible meat from male broilers as influenced by dietary protein level and amino acid supplementation. Canadian Journal Animal Science 1988; 68:241-248.

Summers JD, Spratt D, Atkinson JL. Broiler weight gain and carcass composition when fed diets varying in amino acid balance, dietary energy, and protein level. Poultry Science 1992; 71:263-273.

Waldroup PW. Influence of environmental temperature on protein and amino acid needs of poultry. Federation Proceedings 1982; $41: 2821-2823$ 